Kong. Res. J. 3(1) : 30-31, 2016

ISSN 2349-2694

Kongunadu Arts and Science College, Coimbatore.

\title{
AESCHYNANTHUS PERROTTETII A.DC. (GESNERIACEAE) - A NEW RECORD FOR EASTERN GHATS
}

\author{
Karuppusamy, $S^{*}$. and V. Ravichandran \\ Department of Botany, Centre for Botanical Research, The Madura College (Autonomous), Madurai. \\ *E.mail: ksamytaxonomy@gmail.com
}

\begin{abstract}
Aeschynanthus perrottetii A.DC. (Gesneriaceae) were collected and reported in Kolli hills of Eastern Ghats for its new distributional record. The detailed description and photographs, flowering and fruiting period, distribution and ecological notes are given for its easy location and identification.
\end{abstract}

Keywords: Aeschynanthus perrottetii, Gesneriaceae, Kolli hills of Eastern Ghats.

\section{INTRODUCTION}

The Eastern Ghats, one of the nine floristic zone in southern India extending over $2000 \mathrm{~km}$ stretch of north to south isolated hillocks covering the area under $11^{\circ} 30^{\prime}-21^{\circ} 00^{\prime} \mathrm{N}$ and $77^{\circ} 22^{\prime}-85^{\circ}$ $20^{\prime} \mathrm{E}$. The hill ranges rise from almost sea level to about $1572 \mathrm{~m}$ altitude and spread over three states of India namely Orissa, Andhra Pradesh and Tamil Nadu between the rivers of Mahanathi and Vaigai along the east coast. Ganjam and Mahendragiri ranges in Orissa; Nallamalais, Araku and Sesachalam ranges in Andhra Pradesh; Servarayans, Javadhu, Chitheeri, Pachamalais and Kolli hill ranges in Tamil Nadu are well known biodiversity spots for Eastern Ghats. Many earlier studies are recorded the floristic wealth of Eastern Ghats ranges time to time by various authors (Gamble, 1927; Matthew, 1983-86; Anand et al., 2006; Pullaiah et al., 2007).

During the recent botanical visits of Kolli hills of Eastern Ghats, we collected an interesting epiphytic plant species Aeschynanthus perrottetii (Gesneriaceae). The species is critically analysed with pertinent literature available for Eastern Ghats, it is hitherto unreported by any earlier floristic accounts (Karuppusamy et al., 2001; Pullaiah and Muralidhara Rao, 2002; Pullaiah et al., 2007, Reddy, 2008). These plant species are phytogeographically significance in the Eastern Ghats. Hence the description, phonological data, distribution details, specimen examined, and ecological notes are given here for easy identification. The voucher specimens are deposited in the herbarium of the Department of Botany (Sri Ganesan Herbarium Madura College SGHMC), The Madura College, Madurai.

\section{OBSERVATIONS}

2.1. Aeschynanthus perrottetii A. DC. Prodr. 9: 261. 1865. Gamble, Fl. Madras Pres. 2: 985.1927 (Fig.1).
Epiphytic, trailing subshrub, stem terete, rooting at swollen nodes. Leaves simple, opposite, fleshy, linear-lanceolate to elliptic, $7-8 \times 1.5-2 \mathrm{~cm}$, entire, lateral nerves obscure, mid vein conspicuous, rounded at base, acute at apex. Flowers solitary, rarely paired, terminal or axillary peduncles; bracts minute, linear-lanceolate, up to $3 \mathrm{~mm}$ long. Calyx 5lobed, lobes linear, $0.5-0.8 \mathrm{~mm}$ long, greenish. Corolla tubular, $4.5 \mathrm{~cm}$ long, tube curved, glabrous, mouth bilabiate, oblique, upper lip of 2 small, the lower lip of 3 larger lobes, scarlet with purple lines or spots on the lobes, glandular ciliate. Stamens 4, all perfect, inserted at the middle of the corolla tube, anther 2, oblong, connate at the tips. Ovary oblong or linear, stipitate, 1-celled, ovules on the margins; stigma dilated. Fruits linear, ca $15 \mathrm{~cm}$ long capsule, 2 -valved. Seeds many, small, oblong or linear with hairs at the end and near hilum.

\subsection{Flowering \& Fruiting}

September - February.

\subsection{Specimen examined}

Tamil Nadu: Namakkal district, Kolli hills, Kulivalavu shola, 1.09.2012. (110 19.35' N - 78 21.49') S. Karuppusamy \& V. Ravichandran 15142 (SGHMC).

\subsection{Distribution}

Western Ghats of south India (Endemic), Kolli hills of Eastern Ghats.

\subsection{Ecological notes}

Aschynanthus is a genus of about 150 species of evergreen subtropical plants in the family Gesneriaceae. They are usually trailing epiphytes with brightly coloured tubular flowers that are pollinated by sunbirds. A. perrottetii is an endemic species of Western Ghats and it was not recorded for 
Eastern Ghats so far. This is a first report on the extended distribution of this species into Eastern Ghats range. The plant is growing on Myristica dactyloides, Celtis tymoriensis, Mallotus tetracoccus, Olea glandulifera, Macranga indica and Neolitsea ceylanica.

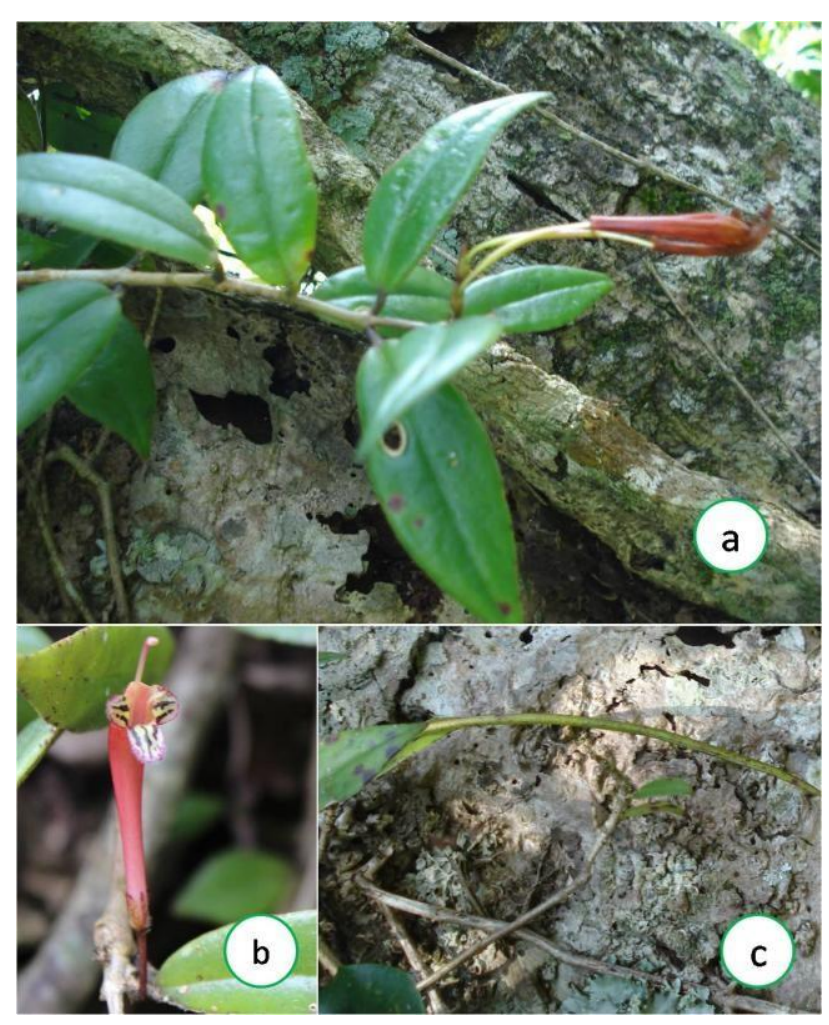

Fig. 1. Aeschynanthus perrottetii A. DC.

\section{REFERENCES}

Anand, R., N. Nandakumar, L. Karunakaran, M. Ragunathan and V. Murugan, (2006). A survey of medicinal plants in Kolli hill tracts, Tamil Nadu. Nat. Prod. Rad. 5(2):139-143.

Gamble, J.S., (1927). Flora of the presidency of Madras, 2 vols. Adlard \& Son Ltd. London.

Karuppusamy, S., (2001). Floristic studies with special reference to Ethnomedicobotany of Sirumalai hills, Tamil Nadu, India. Ph.D. thesis submitted to the Gandhigram University, Tamil Nadu.

Matthew, K.M. (1983-86). The Flora of the Tamilnadu Carnatic. 3 vols. Rapinat Herbarium, Thiruchirappalli, Tamilnadu, India.

Pullaiah, T. and D. Muralidhra Rao, (2002). Flora of Eastern Ghats hill tracts of southeast India. Vol.1. Regency publication, New Delhi.

Pullaiah, T., S. Sandhya Rani and S. Karuppusamy, (2007). Flora of Eastern Ghats hill tracts of southeast India. Vol.4. Regency publication, New Delhi.

Reddy, C.S., (2008). Catalogue of alien flora of India. NRSA, Hydrabad. www.sciencepub. net/life/ life0502/16_life0502_84_89_Catalogue.pdf.

a- Plant in epiphytic habitat; b - Flower; c- Fruit 